\title{
The Effect of Mastoidectomy Combined with Tympanoplasty Type I on Postoperative Hearing in Chronic Otitis Media Patients Older than 65 Years
}

\author{
Chung Man Sung, Hee Young Kim, Jong Min Park, \\ Sungsu Lee, Hyong-Ho Cho, and Yong-Beom Cho \\ Department of Otolaryngology-Head and Neck Surgery, Chonnam National University Medical School and \\ Chonnam National University Hospital, Gwangju, Korea
}

\section{제1형 고실성형술에 동반된 유양돌기절제술이 65 세 이상 고령 만성 중이염 환자의 술후 청력에 미치는 영향}

성충만 · 김희영 · 박종민 · 이성수 · 조형호 · 조용범

전남대학교 의과대학 이비인후과학교실, 전남대학교병원 이비인후과

\author{
Received September 9, 2017 \\ Revised September 28, 2017 \\ Accepted September 29, 2017 \\ Address for correspondence \\ Yong-Beom Cho, MD, PhD \\ Department of Otolaryngology- \\ Head and Neck Surgery, \\ Chonnam National University \\ Medical School and Chonnam \\ National University Hospital, \\ 42 Jebong-ro, Dong-gu, \\ Gwangju 61469, Korea \\ Tel +82-62-220-6776 \\ Fax +82-62-228-7743 \\ E-mail choyb@jnu.ac.kr
}

Background and Objectives Although canal wall up mastoidectomy (CWUM) has been performed frequently as a treatment for chronic otitis media (COM), the necessity of CWUM for non-cholesteatomatous COM (NCCOM) is still controversial. Since elderly people often have systemic problems, there is a high likelihood of side effects after general anesthesia, so it is important to judge the necessity of mastoidectomy. The purpose of this study was to investigate the effect of CWUM for the treatment of NCCOM in patients over 65 years of age.

Subjects and Method Forty-two cases of CWUM with tympanoplasty type I performed as a treatment for NCCOM from 2007 through 2016 were reviewed retrospectively. Pure tone audiometry was performed preoperatively and postoperatively, and preoperative temporal bone CT was used to evaluate the mastoid status. The valsalva maneuver (VM) was used to evaluate the eustachian tube function.

Results The total number of patients was 42 and the success rate of eardrum repair was $92.8 \%$. Comparison of hearing results taken preoperatively and postoperatively showed significant hearing improvement in both air conduction and air-bone gap. When hearing results were compared according to the mastoid status and the response of VM, there were no significant differences.

Conclusion Mastoidectomy combined with tympanoplasty type I showed a high success rate of ear drum repair and good hearing improvement, with no critical side effects. Therefore, mastoidectomy does not need to be limited by one's old age. Adequate mastoidectomy after proper consideration of the mastoid status will be helpful in the treatment of the disease.

Korean J Otorhinolaryngol-Head Neck Surg 2017;60(12):626-32

Key Words Chronic otitis media · Elderly · Hearing · Mastoidectomy ·

Type I tympanoplasty.

This is an Open Access article distributed under the terms of the Creative Commons Attribution Non-Commercial License (http://creativecommons.org/licenses/by-nc/4.0) which permits unrestricted non-commercial use, distribution, and reproduction in any medium, provided the original work is properly cited. 


\section{서 론}

만성 중이염의 수술적 치료로서 고실성형술과 함께 폐쇄 동 유양돌기절제술이 현재도 많이 시행되고 있는데, 이는 중 이강이나 유양돌기 내의 비가역적 병변을 제거하고 청각기전 을 재건하며, 고막 이식을 통한 고막의 천공을 막아 중이를 외부의 유해한 환경으로부터 보호하기 위하여 시행된다. ${ }^{1)}$ 그 러나 항생제의 발달로 중이 내 감염의 조절이 용이해지고, 전 통적으로 유양돌기절제술의 부작용으로 여겨지는 안면 마 비, 뇌척수액 유출, 뇌수막염 등의 발생 위험성으로 인해 진 주종이 없는 단순 만성 중이염의 경우에서 유양돌기절제술 의 역할에 대한 논쟁이 지속되고 있다. ${ }^{2}$ 특히 노령에서의 경우 일반적으로 심혈관 질환이나 대사성 질환, 호흡기 질환 등의 만성 전신성 문제를 가지는 경우가 많아 전신마취에 따른 수 술 후 합병증의 발생 가능성이 올라가므로 이에 대한 판단이 더욱 중요하다. ${ }^{3)}$ 반대로, 만성 중이염의 악화는 환자의 난청 을 유발할 수 있으며, 특히 노인에서 난청은 우울증의 발생률 을 높이고 치매를 악화시킬 수 있어 적절한 치료가 필요하다.

현재까지 노인 환자에서 유양돌기절제술의 효용성에 대한 보고가 매우 미비한 실정이다. 이에 본 연구에서는 65 세 이상 의 환자를 대상으로 진주종이 없는 만성 중이염의 수술적 치 료에서 폐쇄동 유양돌기절제술 결과를 분석하여 노인 환자에 서의 유양돌기절제술의 득실을 알아보고자 하였다.

\section{대상 및 방법}

2007 2016년 전남대학교병원 이비인후과에서 진주종이나 콜레스테롤 육아종 등이 없는 단순 만성 중이염으로 진단받 고 제1형 고실성형술과 함께 폐쇄동 유양돌기절제술을 시행 받은 환자들의 의무기록을 검토하여 65 세 이상의 환자 42명 을 대상으로 하였다. 수술 전에 시행한 신체검진상 고막의 천 공이 확인되며, 측두골 컴퓨터전산화단층촬영을 시행하여 다른 원인이 의심되지 않을 때 만성 중이염으로 진단하였으 며, 수술 중 진주종이나 콜레스테롤 육아종 등 다른 질환이 확인된 경우, 또한 이전에 동측의 귀 수술을 받은 적이 있는 재수술 환자의 경우도 대상에서 제외하였다. 모든 환자들에 게서 수술 전 신체검진과 순음청력검사, 측두골 컴퓨터전산 화단층촬영을 시행하였으며, 발살바법을 통하여 이관 기능 을 평가하였다.

수술 후 신체검진을 통하여 고막의 재천공 및 유착 등을 확 인하여 고막 재생의 성공률을 조사하였고, 추가적으로 지속 적인 이루 및 수술 부위의 감염, 안면신경마비 등의 추가적인 합병증의 발생 여부를 확인하였다.
수술 후(6개월) 순음청력검사가 시행되어 있는 환자 22명을 대상으로 $500,1000,2000,4000 \mathrm{~Hz}$ 의 청각역치를 이용하여 골도청각역치(bone conduction, $\mathrm{BC}$ ), 기도청각역치(air conduction, $\mathrm{AC}$ ), 기도-골도 차(air-bone gap, ABG)를 평가하였다.

수술 전 시행한 측두골 컴퓨터전산화단층촬영 결과를 이용 해 유양동의 함기화 및 경화의 정도를 평가하였다. 유양동은 함기화(pneumatic), 중간(diploic), 경화(sclerotic)로 구분하였 고 유양동의 상태에 따른 술후 청력을 비교하였다.

수술 전 시행한 발살바법의 반응을 통해 이관 기능을 평가 하여 반응의 유무에 따라 양성과 음성의 두 군으로 분류하였 다. 두 군 사이에 수술 전과 후 $\mathrm{BC}, \mathrm{AC}, \mathrm{ABG}$ 의 변화를 비교 하여 발살바법에 의한 이관 기능의 평가와 수술 후 청력과의 연관성을 알아보고자 하였다.

환자의 의무기록을 검토하여 이루의 첫 발생 시기와 수술 전 마지막 발생 시기에 따라 3 군으로 분류하여 이에 따른 술 전, 술후 청력을 비교하였다.

통계학적 분석은 SPSS version 19.0(IBM Corp., Armonk, NY, USA)을 통해 Student's t-test를 사용하여 분석하였으며 $p$ 값이 0.05 미만인 경우에 통계적으로 유의한 것으로 해석하 였다.

본 연구는 전남대학교병원 연구윤리심의 위원회의 심의를 받아 수행되었다(IRB 번호 CNUH-2017-146).

\section{결 과}

총 대상 인원은 42명이었으며, 남성이 19 명, 여성이 23명이 었다. 연령 분포는 65 76세였으며, 평균연령은 69.4세였다. 수술 부위는 우측 귀가 26예, 좌측 귀가 16 예였다. 술전 시행 한 발살바법에서 양성은 27 명, 음성은 15 명이었다. 평균 추적 관찰 기간은 18.9 개월(1 90개월)로 수술 후 추적관찰 중에 4 명에서 재천공이 발생하였으며, 그중 한 명은 자연적으로 봉 합이 되었다. 유착이나 진주종의 발생은 없었으며, 1 명에서 수술 후 안면신경마비가 발생하였으나, 외래 추적관찰 중 호 전을 보였다. 고막천공의 수술 성공률은 $92.8 \%$ 였다. 수술 후 청력 결과가 확인된 22명 중 3명에서 골도청력역치가 $10 \mathrm{~dB}$ 정도의 감소를 보였으나 고도의 감각신경성 난청의 발생은 관찰되지 않았다.

\section{수술 전후 청력 결과}

수술 전과 후에 검사한 순음청력검사의 결과는 Fig. 1과 같 다. 수술 전에 비하여 수술 후 평균 $\mathrm{AC}, \mathrm{ABG}$ 에서 모두 유의 할 만한 청력 개선이 있었음을 알 수 있었다 $(p<0.05)$. 주파수 별로 보면 $500 \mathrm{~Hz}$ 와 $1000 \mathrm{~Hz}$ 에서 청력 증강이 확인되었고 
특이점으로 이들 주파수에서는 $\mathrm{BC}$ 도 통계적으로 유의하게 호전을 보였다 $(p<0.05)$.

\section{유양동의 상태에 따른 청력 결과}

술전 시행한 측두골 전산화단층촬영 영상을 분석하여 함기 화, 중간, 경화의 3 군으로 환자들을 분류하였고, 함기화군은 7 명, 중간군은 1 명, 경화군은 14 명이었다. 중간군은 환자 수 가 적어 통계에서 제외하고, 함기화군과 경화군의 청력 결과 를 비교하였다(Table 1). 수술 전과 후의 청력 결과에서 경화 군이 함기화군에 더 낮은 청력 상태를 보여주었고 특히 술후 $2000 \mathrm{~Hz}$ BC에서는 통계적으로 유의미하게 함기화군이 청력 개선이 있었으나 전체적으로 유의한 차이는 보이지 않았다.

\section{이관 기능에 따른 수술 후 청력 결과}

수술 전 시행한 발살바법을 통해 이관 기능을 평가하였고, 양성군과 음성군으로 분류하여 청력 결과를 비교하였다(Table 2). 술전 청력 결과는 두 군 간에 큰 차이는 보이지 않았으며, 술후 청력 개선 정도에서 양성군이 더 좋은 수치를 보였으나 통계적으로 유의한 차이는 보이지 않았다 $(p>0.05)$.

\section{수술 전 이루의 발생 시기에 따른 청력 결과}

이루의 발생 시기 및 술전 마지막 이루의 시기에 따른 청력 결과를 비교하였다(Table 3 and 4). 첫 이루의 발생 시기에 따 른 청력 결과에서는 차이가 보이지 않았다. 수술 전 마지막 이
루의 시기에 따른 결과에서는 수술 후 골도청력 2000, 4000 $\mathrm{Hz}$, 수술 후 기도청력 $2000 \mathrm{~Hz}$ 에서 유의한 차이를 보였으나 그 외에 유의한 차이는 보이지 않았다.

\section{고 찰}

폐쇄동 유양돌기절제술은 만성 중이염의 수술적 치료에서 더 나은 결과를 얻기 위한 이비인후과 의사들의 노력들 가운 데서 고전적인 유양돌기절제술이 변형되어 발생한 방법이다. 이전의 많은 저자들은 성공적인 수술 결과를 얻기 위하여 고 실성형술과 함께 유양돌기삭개술을 같이 시행하는 것을 추천 하고 있고, 유양돌기삭개술의 시행은 중이 내 압력 변화에 대 한 완충 작용을 위한 공기 저장소를 제공하고 유양동 내에 숨 어 있는 병변을 제거하는 데 도움을 줄 것으로 생각된다. ${ }^{4)}$ 진 주종성 만성 중이염에서 유양돌기절제술의 시행은 많은 이 비인후과 의사들에게 지지를 받고 있지만, 진주종이 없는 단 순 만성 중이염에서 유양돌기삭개술의 시행은 아직도 논란으 로 남아 있는 상태이다. ${ }^{5)}$

본 연구의 술후 청력 결과를 보면 술전 청력에 비해서 평균 $\mathrm{BC}, \mathrm{AC}, \mathrm{ABG}$ 에서 모두 유의한 청력 개선을 보여, 폐쇄동 유 양돌기절제술이 단순 만성 중이염의 치료에 충분히 효과적 인 방법임을 알 수 있었다. 주파수별 청력 변화를 살펴보면 $500,1000 \mathrm{~Hz}$ 의 저주파수에서 $2000,4000 \mathrm{~Hz}$ 의 고주파수에 비해 더 나은 청력 개선을 보이고 있었는데, 이는 고막의 천공

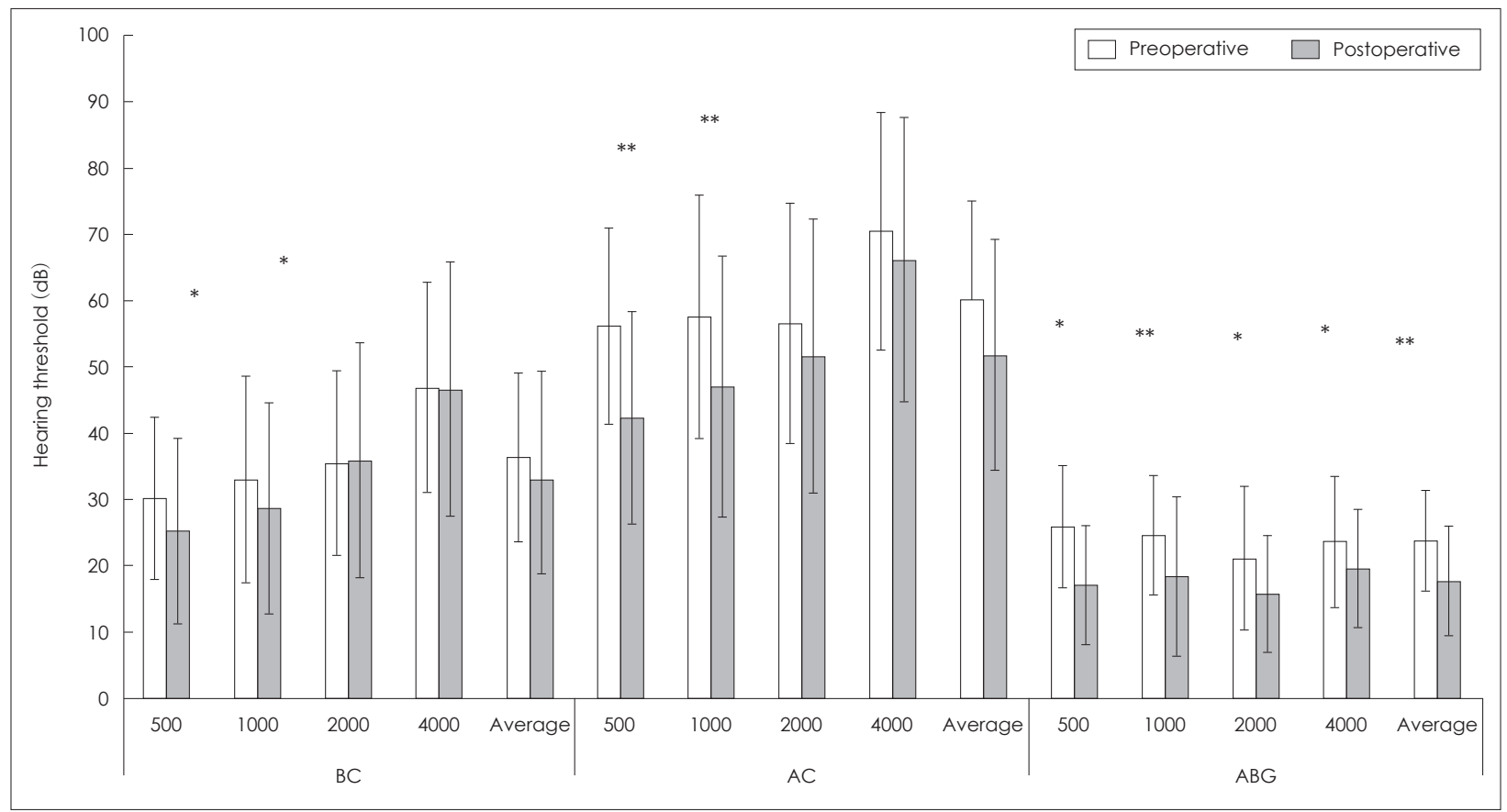

Fig. 1. Comparison between preoperative and postoperative hearing in overall patients. ${ }^{*} p<0.05,{ }^{* *} p<0.01$. BC: bone conduction, $A C$ : air conduction, $A B G$ : air-bone gap. 
에 의한 청력저하가 저주파수에 더 많은 영향을 주기 때문으 로 생각된다. 고실성형술의 고막 재생 성공률은 다양하게 보 고되고 있지만 유양돌기삭개술의 동반 시행 여부와 상관없 이 일반적으로 $80 \%$ 이상에서 성공적인 고막 재생이 이루어지 는 것으로 생각된다. ${ }^{6,7)}$ 본 연구 결과에서는 수술 후 재천공이 나 그 외에 합병증은 발생하지 않았으나 이는 수술 후 청력 결

Table 1. Hearing result according to mastoid status

\begin{tabular}{|c|c|c|c|}
\hline & $\begin{array}{l}\text { Pneumatic }(\mathrm{dB}) \\
(\mathrm{n}=7)\end{array}$ & $\begin{array}{c}\text { Sclerotic }(d B) \\
(n=14)\end{array}$ & $p$ value \\
\hline \multicolumn{4}{|l|}{ Preoperative } \\
\hline \multicolumn{4}{|l|}{$B C$} \\
\hline 500 & $24.28 \pm 10.17$ & $32.85 \pm 12.81$ & 0.141 \\
\hline 1000 & $27.14 \pm 15.23$ & $35.00 \pm 15.93$ & 0.294 \\
\hline 2000 & $31.42 \pm 10.69$ & $36.78 \pm 15.64$ & 0.427 \\
\hline 4000 & $41.42 \pm 16.51$ & $48.92 \pm 15.95$ & 0.328 \\
\hline Average & $31.07 \pm 11.71$ & $38.39 \pm 13.09$ & 0.227 \\
\hline \multicolumn{4}{|l|}{$A C$} \\
\hline 500 & $47.85 \pm 10.74$ & $59.28 \pm 15.42$ & 0.096 \\
\hline 1000 & $51.42 \pm 16.25$ & $59.28 \pm 19.49$ & 0.371 \\
\hline 2000 & $54.28 \pm 16.43$ & $56.42 \pm 19.45$ & 0.806 \\
\hline 4000 & $70.71 \pm 19.88$ & $70.00 \pm 18.39$ & 0.936 \\
\hline Average & $56.07 \pm 12.95$ & $61.25 \pm 16.03$ & 0.469 \\
\hline \multicolumn{4}{|l|}{$A B G$} \\
\hline 500 & $23.57 \pm 9.44$ & $26.42 \pm 9.28$ & 0.517 \\
\hline 1000 & $24.28 \pm 7.31$ & $24.28 \pm 10.16$ & 1.000 \\
\hline 2000 & $22.85 \pm 12.53$ & $19.64 \pm 10.27$ & 0.537 \\
\hline 4000 & $29.28 \pm 10.57$ & $21.07 \pm 9.02$ & 0.079 \\
\hline Average & $25.00 \pm 7.50$ & $22.85 \pm 7.97$ & 0.561 \\
\hline \multicolumn{4}{|l|}{ Postoperative } \\
\hline \multicolumn{4}{|l|}{$B C$} \\
\hline 500 & $18.57 \pm 14.05$ & $27.85 \pm 13.68$ & 0.163 \\
\hline 1000 & $20.71 \pm 12.05$ & $32.14 \pm 17.17$ & 0.133 \\
\hline 2000 & $25.00 \pm 11.18$ & $40.35 \pm 18.75$ & $0.031 *$ \\
\hline 4000 & $37.85 \pm 15.23$ & $50.35 \pm 20.70$ & 0.175 \\
\hline Average & $25.53 \pm 11.24$ & $37.67 \pm 16.02$ & 0.090 \\
\hline \multicolumn{4}{|l|}{$A C$} \\
\hline 500 & $36.42 \pm 15.99$ & $43.57 \pm 15.37$ & 0.334 \\
\hline 1000 & $35.71 \pm 13.97$ & $50.71 \pm 19.98$ & 0.093 \\
\hline 2000 & $40.71 \pm 12.72$ & $55.00 \pm 21.83$ & 0.075 \\
\hline 4000 & $59.28 \pm 19.02$ & $67.85 \pm 22.50$ & 0.399 \\
\hline Average & $43.03 \pm 12.32$ & $54.28 \pm 18.05$ & 0.156 \\
\hline \multicolumn{4}{|l|}{$A B G$} \\
\hline 500 & $17.85 \pm 6.98$ & $15.71 \pm 9.57$ & 0.607 \\
\hline 1000 & $15.00 \pm 10.00$ & $18.57 \pm 11.99$ & 0.507 \\
\hline 2000 & $15.71 \pm 6.07$ & $14.64 \pm 9.49$ & 0.790 \\
\hline 4000 & $21.42 \pm 6.90$ & $17.50 \pm 8.93$ & 0.322 \\
\hline Average & $17.50 \pm 5.49$ & $16.60 \pm 8.69$ & 0.808 \\
\hline
\end{tabular}

$* p<0.05 . B C$ : bone conduction, $A C$ : air conduction, $A B G$ : airbone gap
과가 있는 환자들을 대상으로 연구를 진행하여, 환자 수가 많 지 않다는 한계가 있다.

유양동의 상태에 따른 청력 결과에서는 함기화군과 경화군 사이에 유의한 차이는 보이지 않았다. 하지만, 경화군에서 함 기화군에 비하여 고주파수에서 더 낮은 청력 개선을 보여주 었는데, 이는 드릴의 소음에 의한 내이의 손상이 고주파에 더

Table 2. Hearing result according to Eustachian tube function (valsalva)

\begin{tabular}{|c|c|c|c|}
\hline & $\begin{array}{c}\text { Positive (dB) } \\
(n=14)\end{array}$ & $\begin{array}{c}\text { Negative (dB) } \\
(n=8)\end{array}$ & $p$ value \\
\hline \multicolumn{4}{|l|}{ Preoperative } \\
\hline \multicolumn{4}{|l|}{$B C$} \\
\hline 500 & $32.50 \pm 12.36$ & $26.25 \pm 11.57$ & 0.257 \\
\hline 1000 & $34.64 \pm 14.99$ & $30.00 \pm 17.32$ & 0.516 \\
\hline 2000 & $36.07 \pm 12.73$ & $34.37 \pm 16.78$ & 0.791 \\
\hline 4000 & $47.14 \pm 15.65$ & $46.25 \pm 17.26$ & 0.903 \\
\hline Average & $37.58 \pm 12.19$ & $34.21 \pm 14.09$ & 0.562 \\
\hline \multicolumn{4}{|l|}{$A C$} \\
\hline 500 & $56.42 \pm 16.34$ & $55.62 \pm 12.65$ & 0.906 \\
\hline 1000 & $58.21 \pm 17.49$ & $56.25 \pm 21.17$ & 0.817 \\
\hline 2000 & $58.21 \pm 18.77$ & $53.75 \pm 17.87$ & 0.591 \\
\hline 4000 & $72.14 \pm 17.17$ & $67.50 \pm 20.17$ & 0.573 \\
\hline Average & $61.25 \pm 14.46$ & $58.28 \pm 16.50$ & 0.664 \\
\hline \multicolumn{4}{|l|}{$A B G$} \\
\hline 500 & $23.92 \pm 10.22$ & $29.37 \pm 6.23$ & 0.189 \\
\hline 1000 & $23.57 \pm 8.64$ & $26.25 \pm 9.91$ & 0.515 \\
\hline 2000 & $22.14 \pm 11.88$ & $19.37 \pm 9.03$ & 0.576 \\
\hline 4000 & $25.00 \pm 11.92$ & $21.25 \pm 4.43$ & 0.305 \\
\hline Average & $23.66 \pm 8.72$ & $24.06 \pm 5.62$ & 0.908 \\
\hline \multicolumn{4}{|l|}{ Postoperative } \\
\hline \multicolumn{4}{|l|}{$B C$} \\
\hline 500 & $25.71 \pm 14.78$ & $24.37 \pm 13.47$ & 0.835 \\
\hline 1000 & $29.28 \pm 13.84$ & $27.50 \pm 20.17$ & 0.808 \\
\hline 2000 & $34.64 \pm 17.03$ & $38.12 \pm 19.98$ & 0.669 \\
\hline 4000 & $45.35 \pm 18.95$ & $48.75 \pm 20.83$ & 0.701 \\
\hline Average & $33.75 \pm 14.37$ & $34.68 \pm 17.69$ & 0.894 \\
\hline \multicolumn{4}{|l|}{$A C$} \\
\hline 500 & $41.07 \pm 18.10$ & $44.37 \pm 12.37$ & 0.653 \\
\hline 1000 & $44.28 \pm 17.19$ & $51.87 \pm 24.19$ & 0.451 \\
\hline 2000 & $48.92 \pm 19.72$ & $56.25 \pm 22.79$ & 0.438 \\
\hline 4000 & $64.64 \pm 20.89$ & $68.75 \pm 23.71$ & 0.677 \\
\hline Average & $49.73 \pm 16.78$ & $55.31 \pm 19.31$ & 0.485 \\
\hline \multicolumn{4}{|l|}{$A B G$} \\
\hline 500 & $15.35 \pm 8.87$ & $20.00 \pm 8.86$ & 0.251 \\
\hline 1000 & $15.00 \pm 11.26$ & $24.37 \pm 11.47$ & 0.077 \\
\hline 2000 & $14.28 \pm 8.73$ & $18.12 \pm 8.83$ & 0.335 \\
\hline 4000 & $19.28 \pm 9.97$ & $20.00 \pm 7.07$ & 0.861 \\
\hline Average & $15.98 \pm 8.81$ & $20.62 \pm 6.74$ & 0.213 \\
\hline
\end{tabular}

$B C$ : bone conduction, $A C$ : air conduction, $A B G$ : air-bone gap 
큰 영향을 미치며, 또한 유양동이 딱딱한 경화군에서 더 크 게 영향을 준다는 추측을 가능하게 한다. ${ }^{89}$ 하지만 이는 통 계적으로 유의한 차이는 보이지 않았고, 이는 숙련도의 차이 는 있겠으나 충분히 숙련된 술자가 수술을 진행할 경우 드릴 소음에 의한 내이 손상이 크지 않음을 알 수 있었다.

고실성형술 후 예후를 결정하는 가장 중요한 인자로 이관 기능이 언급되어 있으나 술전의 이관 기능 평가와 예후와의
연관성에 관해서는 많은 논란이 있다. ${ }^{10-14)}$ 본 연구에서는 수 술 전 시행한 발살바법에 의해 양성과 음성의 두 군으로 나누 어 청력 결과를 비교하였고, 양성인 군에서 음성인 군에 비 하여 수술 후 더 나은 청력 개선을 보였지만, 통계학적으로 유의한 차이는 아니었다. 이는 발살바법이 수술 후 예후를 추 측하는 데 도움을 줄 수는 있지만, 예후 평가에 훌륭한 방법 은 아님을 알 수 있었다. 물론 다른 이관기능평가를 위한 검

Table 3. Hearing result according to onset of otorrhea

\begin{tabular}{|c|c|c|c|c|}
\hline & $<1$ year $(n=6)$ & $1-5$ years $(n=4)$ & $>5$ years $(n=8)$ & $p$ value \\
\hline \multicolumn{5}{|l|}{ Preoperative } \\
\hline \multicolumn{5}{|l|}{$B C$} \\
\hline 500 & $30.00 \pm 12.64$ & $35.00 \pm 8.16$ & $30.00 \pm 16.25$ & 0.817 \\
\hline 1000 & $35.00 \pm 13.03$ & $37.50 \pm 16.58$ & $30.62 \pm 20.43$ & 0.794 \\
\hline 2000 & $36.66 \pm 9.30$ & $33.75 \pm 17.50$ & $37.50 \pm 17.92$ & 0.924 \\
\hline 4000 & $55.83 \pm 7.35$ & $45.00 \pm 14.71$ & $42.50 \pm 19.08$ & 0.280 \\
\hline Average & $39.37 \pm 7.10$ & $37.81 \pm 13.32$ & $35.15 \pm 17.55$ & 0.853 \\
\hline \multicolumn{5}{|l|}{$A C$} \\
\hline 500 & $52.50 \pm 11.72$ & $60.00 \pm 12.90$ & $58.12 \pm 19.80$ & 0.734 \\
\hline 1000 & $55.83 \pm 12.81$ & $63.75 \pm 19.31$ & $57.50 \pm 24.05$ & 0.820 \\
\hline 2000 & $54.16 \pm 12.00$ & $56.25 \pm 24.95$ & $61.87 \pm 18.69$ & 0.725 \\
\hline 4000 & $75.00 \pm 13.41$ & $70.00 \pm 18.25$ & $70.00 \pm 20.17$ & 0.855 \\
\hline Average & $59.37 \pm 11.44$ & $62.50 \pm 16.80$ & $61.87 \pm 18.11$ & 0.942 \\
\hline \multicolumn{5}{|l|}{$A B G$} \\
\hline 500 & $22.50 \pm 14.74$ & $25.00 \pm 5.77$ & $28.12 \pm 7.03$ & 0.595 \\
\hline 1000 & $20.83 \pm 10.68$ & $26.25 \pm 11.08$ & $26.87 \pm 7.03$ & 0.468 \\
\hline 2000 & $17.50 \pm 12.14$ & $22.50 \pm 15.00$ & $24.37 \pm 8.21$ & 0.532 \\
\hline 4000 & $19.16 \pm 13.19$ & $25.00 \pm 9.12$ & $27.50 \pm 8.86$ & 0.363 \\
\hline Average & $20.00 \pm 10.92$ & $24.68 \pm 8.91$ & $26.71 \pm 4.16$ & 0.320 \\
\hline \multicolumn{5}{|l|}{ Postoperative } \\
\hline \multicolumn{5}{|l|}{$B C$} \\
\hline 500 & $27.50 \pm 11.72$ & $32.50 \pm 9.57$ & $23.12 \pm 17.91$ & 0.581 \\
\hline 1000 & $30.83 \pm 11.14$ & $32.50 \pm 15.00$ & $28.12 \pm 22.66$ & 0.916 \\
\hline 2000 & $38.33 \pm 9.30$ & $37.50 \pm 23.27$ & $37.50 \pm 22.03$ & 0.996 \\
\hline 4000 & $48.33 \pm 17.22$ & $57.50 \pm 18.92$ & $45.62 \pm 22.10$ & 0.628 \\
\hline Average & $36.25 \pm 10.78$ & $40.00 \pm 13.73$ & $33.59 \pm 20.20$ & 0.815 \\
\hline \multicolumn{5}{|l|}{$A C$} \\
\hline 500 & $41.66 \pm 16.63$ & $47.50 \pm 11.90$ & $40.00 \pm 18.51$ & 0.765 \\
\hline 1000 & $45.00 \pm 16.12$ & $50.00 \pm 17.79$ & $48.75 \pm 25.31$ & 0.922 \\
\hline 2000 & $52.50 \pm 18.37$ & $52.50 \pm 23.27$ & $55.00 \pm 21.38$ & 0.969 \\
\hline 4000 & $64.16 \pm 25.18$ & $72.50 \pm 9.57$ & $69.37 \pm 23.66$ & 0.833 \\
\hline Average & $50.83 \pm 17.44$ & $55.62 \pm 10.82$ & $53.28 \pm 20.78$ & 0.918 \\
\hline \multicolumn{5}{|l|}{$A B G$} \\
\hline 500 & $14.16 \pm 11.14$ & $15.00 \pm 7.07$ & $16.87 \pm 8.83$ & 0.860 \\
\hline 1000 & $14.16 \pm 12.81$ & $17.50 \pm 11.90$ & $20.62 \pm 12.37$ & 0.637 \\
\hline 2000 & $14.16 \pm 12.41$ & $15.00 \pm 4.08$ & $17.50 \pm 8.01$ & 0.785 \\
\hline 4000 & $15.83 \pm 8.61$ & $15.00 \pm 10.00$ & $23.75 \pm 7.44$ & 0.150 \\
\hline Average & $14.58 \pm 10.08$ & $15.62 \pm 7.93$ & $19.68 \pm 7.03$ & 0.503 \\
\hline
\end{tabular}

$\mathrm{BC}$ : bone conduction, $\mathrm{AC}$ : air conduction, $\mathrm{ABG}$ : air-bone gap 
사들에 비하여 간단히 검사를 시행할 수 있는 발살바법의 편의성을 생각하면 수술 후 예후 예측을 위하여 시행하는 것 이 나쁘지 않을 것으로 생각된다.

이루의 첫 발생 시기를 통해 만성 중이염의 발생 시기로 고 려하여 만성 중이염의 유병 기간을 분류하여 청력 결과를 비 교하였다. 만성 중이염의 유병 기간이 증가할수록 감각신경성 난청이 악화된다는 이전 보고 ${ }^{15)}$ 와 같이 이루의 발생이 오래된
환자에서 더 낮은 청력 상태를 보일 것으로 생각하였으나, 본 연구에서는 유의한 차이는 보이지 않았다. 또한 마지막 이루 의 시기에 따라 수술 후 청력 결과에서도 차이가 있을 것으로 생각하였으나, 유의한 차이는 보이지 않았다. 이를 통해 유양 돌기절제술이 이루가 있는 만성 중이염의 치료에도 효과적임 을 알 수 있었다.

노령에서 유양돌기절제술의 유용성에 대한 Ahn 등하의 보

Table 4. Hearing result according to onset of last-otorrhea

\begin{tabular}{|c|c|c|c|c|}
\hline & $<1$ week $(n=5)$ & 1 week -1 month $(n=10)$ & $>1$ month $(n=7)$ & p value \\
\hline \multicolumn{5}{|l|}{ Preoperative } \\
\hline \multicolumn{5}{|l|}{$B C$} \\
\hline 500 & $29.00 \pm 13.87$ & $32.50 \pm 15.32$ & $27.85 \pm 4.87$ & 0.738 \\
\hline 1000 & $29.00 \pm 19.81$ & $39.50 \pm 15.35$ & $26.42 \pm 10.29$ & 0.198 \\
\hline 2000 & $33.00 \pm 14.83$ & $40.00 \pm 15.98$ & $30.71 \pm 9.32$ & 0.383 \\
\hline 4000 & $38.00 \pm 18.23$ & $55.00 \pm 12.47$ & $41.42 \pm 14.63$ & 0.075 \\
\hline Average & $32.25 \pm 15.79$ & $41.75 \pm 12.50$ & $31.60 \pm 8.59$ & 0.196 \\
\hline \multicolumn{5}{|l|}{$A C$} \\
\hline 500 & $57.00 \pm 18.23$ & $58.50 \pm 15.64$ & $52.14 \pm 12.19$ & 0.697 \\
\hline 1000 & $54.00 \pm 24.34$ & $65.00 \pm 15.27$ & $49.28 \pm 16.18$ & 0.205 \\
\hline 2000 & $55.00 \pm 16.58$ & $59.00 \pm 19.55$ & $54.28 \pm 19.45$ & 0.861 \\
\hline 4000 & $62.00 \pm 16.43$ & $79.50 \pm 17.07$ & $63.57 \pm 16.25$ & 0.092 \\
\hline Average & $57.00 \pm 15.17$ & $65.50 \pm 15.06$ & $54.82 \pm 13.98$ & 0.315 \\
\hline \multicolumn{5}{|l|}{$A B G$} \\
\hline 500 & $28.00 \pm 7.58$ & $26.00 \pm 11.00$ & $24.28 \pm 8.38$ & 0.804 \\
\hline 1000 & $25.00 \pm 7.90$ & $25.50 \pm 9.55$ & $22.85 \pm 9.94$ & 0.844 \\
\hline 2000 & $22.00 \pm 10.36$ & $19.00 \pm 11.00$ & $23.57 \pm 11.80$ & 0.698 \\
\hline 4000 & $24.00 \pm 11.93$ & $24.50 \pm 7.61$ & $22.14 \pm 12.53$ & 0.896 \\
\hline Average & $24.75 \pm 6.08$ & $23.75 \pm 8.31$ & $23.21 \pm 8.50$ & 0.947 \\
\hline \multicolumn{5}{|l|}{ Postoperative } \\
\hline \multicolumn{5}{|l|}{$B C$} \\
\hline 500 & $23.00 \pm 16.04$ & $29.50 \pm 14.61$ & $20.71 \pm 11.70$ & 0.431 \\
\hline 1000 & $29.00 \pm 20.43$ & $34.00 \pm 16.79$ & $20.71 \pm 8.38$ & 0.250 \\
\hline 2000 & $36.00 \pm 17.81$ & $45.00 \pm 15.98$ & $22.85 \pm 13.18$ & $0.032 *$ \\
\hline 4000 & $42.00 \pm 21.67$ & $57.00 \pm 15.84$ & $35.00 \pm 15.81$ & $0.048^{*}$ \\
\hline Average & $32.50 \pm 17.94$ & $41.37 \pm 14.14$ & $24.82 \pm 10.41$ & 0.079 \\
\hline \multicolumn{5}{|l|}{$A C$} \\
\hline 500 & $42.00 \pm 16.80$ & $43.50 \pm 15.46$ & $40.71 \pm 18.58$ & 0.944 \\
\hline 1000 & $45.00 \pm 20.00$ & $52.00 \pm 20.97$ & $41.42 \pm 19.08$ & 0.560 \\
\hline 2000 & $57.00 \pm 14.40$ & $60.00 \pm 18.25$ & $35.71 \pm 20.49$ & $0.038^{*}$ \\
\hline 4000 & $63.00 \pm 13.50$ & $76.00 \pm 22.58$ & $54.28 \pm 19.88$ & 0.111 \\
\hline Average & $51.75 \pm 14.26$ & $57.87 \pm 17.53$ & $43.03 \pm 18.01$ & 0.236 \\
\hline \multicolumn{5}{|l|}{$A B G$} \\
\hline 500 & $19.00 \pm 10.83$ & $14.00 \pm 8.09$ & $20.00 \pm 8.66$ & 0.357 \\
\hline 1000 & $16.00 \pm 9.61$ & $18.00 \pm 13.78$ & $20.71 \pm 12.05$ & 0.806 \\
\hline 2000 & $21.00 \pm 4.18$ & $15.00 \pm 9.71$ & $12.85 \pm 9.06$ & 0.281 \\
\hline 4000 & $21.00 \pm 9.61$ & $19.00 \pm 8.75$ & $19.28 \pm 9.75$ & 0.922 \\
\hline Average & $19.25 \pm 7.42$ & $16.50 \pm 8.57$ & $18.21 \pm 9.37$ & 0.828 \\
\hline
\end{tabular}

$* p<0.05$. BC: bone conduction, $A C$ : air conduction, $A B G$ : air-bone gap 
고에 의하면 젊은 환자군에 비하여 노령 환자에서 특별한 합 병증 발생의 증가는 보이지 않았으며, 청력의 개선 정도 및 재 수술의 비율에서도 특별한 차이는 보이지 않았다. 본 연구에 서도 고막 재생의 성공률, 청력의 개선 정도, 합병증의 발생 빈도 등에서 이전의 보고들과 비슷한 결과를 보였는데, 이는 노령에서도 유양돌기절제술이 만성 중이염의 치료로서 충분 히 효과적임을 보여주는 결과이다.

저자들이 생각하는 본 연구의 제한점으로는 연구 대상자의 수가 너무 적다는 것이다. 이는 65세 이상의 환자들에서 앞에 언급하였던 포함 및 제외 기준을 만족하는 환자들의 수가 적 었고, 수술 후 청력검사가 시행된 환자들의 수가 적었기 때문 으로 추후 더 많은 자료의 수집이 필요할 것으로 생각된다. 또한, 유양돌기절제술에 대한 적절한 비교 대상이 없다는 점 도 이 연구의 한계로 생각된다. 본 연구에 앞서 유양돌기절제 술에 대한 비교 대상으로서 제1형 고실성형술을 시행한 환 자들의 자료를 수집하였으나, 수술 전 청력 상태에서 유의한 차이를 보여 동일한 환자군으로서 적절한 비교 대상이 아니 라고 판단되어 유양돌기절제술의 효과에 대해서만 분석을 진행하였다.

\section{REFERENCES}

1) Brackmann DE. Tympanoplasty with mastoidectomy: canal wall up procedures. Am J Otol 1993;14(4):380-2.

2) McGrew BM, Jackson CG, Glasscock ME 3rd. Impact of mastoidectomy on simple tympanic membrane perforation repair. Laryngoscope 2004;114(3):506-11.

3) Kanonidou Z, Karystianou G. Anesthesia for the elderly. Hippokratia 2007;11(4):175-7.
4) Ruhl CM, Pensak ML. Role of aerating mastoidectomy in noncholesteatomatous chronic otitis media. Laryngoscope 1999;109 (12):1924-7.

5) Eliades SJ, Limb CJ. The role of mastoidectomy in outcomes following tympanic membrane repair: a review. Laryngoscope 2013;123(7): 1787-802.

6) Albu S, Trabalzini F, Amadori M. Usefulness of cortical mastoidectomy in myringoplasty. Otol Neurotol 2012;33(4):604-9.

7) Ramakrishnan A, Panda NK, Mohindra S, Munjal S. Cortical mastoidectomy in surgery of tubotympanic disease. Are we overdoing it? Surgeon 2011;9(1):22-6.

8) Banakis Hartl RM, Mattingly JK, Greene NT, Farrell NF, Gubbels SP, Tollin DJ. Drill-induced cochlear injury during otologic surgery: intracochlear pressure evidence of acoustic trauma. Otol Neurotol 2017;38(7):938-47.

9) Kazikdas KC, Onal K, Yildirim N. Sensorineural hearing loss after ossicular manipulation and drill-generated acoustic trauma in type I tympanoplasty with and without mastoidectomy: a series of 51 cases. Ear Nose Throat J 2015;94(9):378-98.

10) Javia LR, Ruckenstein MJ. Ossiculoplasty. Otolaryngol Clin North Am 2006;39(6):1177-89.

11) Sato H, Nakamura H, Honjo I, Hayashi M. Eustachian tube function in tympanoplasty. Acta Otolaryngol Suppl 1990;471:9-12.

12) Lin AC, Messner AH. Pediatric tympanoplasty: factors affecting success. Curr Opin Otolaryngol Head Neck Surg 2008;16(1):64-8.

13) Priya K, Karthikeyan P, Coumare VN, Sambandan AP. Evaluation of Eustachian tube function in chronic suppurative otitis media (tubotympanic type) with reference to its treatment outcome. Indian J Otol 2012;18(4):179-83.

14) Kim YH, Maeng JW, Kim HJ. Eustachian Tube Function and Mastoid Pneumatization as Prognostic Factors of Type 1 Tympanoplasty. Korean J Otorhinolaryngol-Head Neck Surg 2012;55(5):284-9.

15) Sakagami M, Maeda A, Node M, Sone M, Mishiro Y. Long-term observation on hearing change in patients with chronic otitis media. Auris Nasus Larynx 2000;27(2):117-20.

16) Ahn JH, An YS, Bae JS, Kim DY. Postoperative results of tympanoplasty with mastoidectomy in elderly patients with chronic otitis media. Ann Otol Rhinol Laryngol 2012;121(3):168-73. 